\title{
Molecular detection of Setaria tundra (Nematoda: Filarioidea) and an unidentified filarial species in mosquitoes in Germany
}

Christina Czajka ${ }^{1,2}$, Norbert Becker ${ }^{1,2}$, Sven Poppert ${ }^{3}$, Hanna Jöst ${ }^{1,2}$, Jonas Schmidt-Chanasit ${ }^{4}$ and Andreas Krüger ${ }^{5^{*}}$

\begin{abstract}
Background: Knowledge of the potential vector role of Culicidae mosquitoes in Germany is very scanty, and until recently it was generally assumed that they are not involved in the transmission of anthroponotic or zoonotic pathogens in this country. However, anticipated changes in the course of global warming and globalization may alter their status.
\end{abstract}

Methods: We conducted a molecular mass screening of mosquitoes for filarial parasites using mitochondrial $12 S$ rRNA-based real-time PCR.

Results: No parasites causing disease in humans such as Dirofilaria spp. were detected in about 83,000 mosquitoes tested, which had been collected in 2009 and 2010 in 16 locations throughout Germany. However, minimum infection rates of up to 24 per 1000 mosquitoes were revealed, which could be attributed to mosquito infection with Setaria tundra and a yet unidentified second parasite. Setaria tundra was found to be widespread in southern Germany in various mosquito species, except Culex spp. In contrast, the unidentified filarial species was exclusively found in Culex spp. in northern Baden-Württemberg, and is likely to be a bird parasite.

Conclusions: Although dirofilariasis appears to be emerging and spreading in Europe, the absence of Dirofilaria spp. or other zoonotic filariae in our sample allows the conclusion that the risk of autochthonous infection in Germany is still very low. Potential vectors of S. tundra in Germany are Ochlerotatus sticticus, Oc. cantans, Aedes vexans and Anopheles claviger. Technically, the synergism between entomologists, virologists and parasitologists, combined with state-of-the-art methods allows a very efficient near-real-time monitoring of a wide spectrum of both human and veterinary pathogens, including new distribution records of parasite species and the incrimination of their potential vectors.

Keywords: Culicidae, filariae, Setaria tundra, mtDNA marker, Germany

\section{Background}

Filariae (order Spirurida, superfamily Filarioidea) represent a relatively small group of tissue-dwelling, parasitic nematodes with great impact on human and animal health [1]. Those of highest medical relevance are the causative agents of lymphatic filariasis (Wuchereria bancrofti and others) and onchocerciasis (Onchocerca volvulus), both diseases with anthroponotic cycles. Several other filarioses are truly enzootic, e.g. in ungulates

\footnotetext{
* Correspondence: krueger@bnitm.de

${ }^{5}$ Department of Tropical Medicine, Bundeswehr Hospital Hamburg,

Hamburg, Germany

Full list of author information is available at the end of the article
}

(animal onchocerciasis) or rodents (Litomosoides sp.), but a few may be transmissible on rare occasions from animals to humans, such as dirofilariasis [2-4] or accidental onchocerciasis $[5,6]$. Although dirofilariasis has been diagnosed in Germany both in humans and dogs, it is assumed that most dog cases and all human cases were imported from endemic regions outside Germany [7-9]. However, more recently Dirofilaria spp. are considered emerging agents of parasitic zoonoses in Europe with a northward trend of expansion [10].

In general, filarioses are vector-borne infections transmitted by various haematophagous arthropods, e.g. insects such as mosquitoes (Culicidae) or arachnids
C Biomed Central

(C) 2012 Czajka et al; licensee BioMed Central Ltd. This is an Open Access article distributed under the terms of the Creative Commons Attribution License (http://creativecommons.org/licenses/by/2.0), which permits unrestricted use, distribution, and reproduction in any medium, provided the original work is properly cited. 
such as mites (Acari) [11,12]. However, the role of particular vectors in the transmission cycles of many filarial species, and their geographical distribution remain largely unknown. These gaps can partially be attributed to the very laborious screening techniques used until recently. If infectivity, prevalence, and parasite identity were to be determined from a vector, large numbers of the arthropods had to be collected and freshly dissected.

Nowadays, molecular techniques are frequently used to detect filarial species in arthropods [13-16]. They allow a much faster throughput and less specimen handling, which is of particular relevance when the prevalence of the parasite is very low. However, these techniques can only provide information about the presence of particular parasites; they do not allow definite conclusions about the natural vector status or infectivity, unless the different body segments such as heads of the insects are screened separately.

Filarial species (for authority names and dates of filarial species please refer to $[12,17])$, known in mammals from Germany include Onchocerca flexuosa, O. skrjabini (syn. O. tarsicola) and O. jakutensis (all in red deer; [18]), O. gutturosa and O. lienalis (in cattle; [19]), Dirofilaria immitis and D. repens (from dogs and humans, but presumably all imported; $[9,20]$ ), Setaria tundra (in roedeer; [21]), Parafilaria bovicola (in cattle; [22]), and Cercopithifilaria rugosicauda (in roe-deer; [23]). Besides these, bird filariae, for example Cardiofilaria, Eufilaria or Sarconema can be expected in Germany [12].

The vectors of the filariae mentioned in Germany are to a large extent unknown. Schulz-Key and Wenk [24] incriminated Simulium ornatum and Prosimulium nigripes as natural vectors of the red deer parasite $O$. tarsicola (= O. skrjabini). Beyond that, it can be assumed from studies in other European countries and in Japan that several Onchocerca spp. are transmitted by blackflies and biting midges [12,25,26], the Dirofilaria species by various mosquitoes (Italy: [27]), Eufilaria spp. by biting midges (France: [12]) and Setaria tundra by Aedes mosquitoes (Finland: [28]).

In order to (i) further clarify the occurrence of mosquito-borne filariae in Germany, (ii) identify their potential vectors, and (iii) monitor the possible introduction or expansion of parasites due to climate change or globalization, we conducted a mass collection of mosquitoes in 2009 and 2010. Alongside a screening for arboviruses in German mosquitoes [29-31], the same mosquito specimens were co-tested for the presence of filariae. In addition, mosquitoes were tested for filariae that were not included in the arbovirus screening.

\section{Methods}

All procedures basically followed those used in the previously established arbovirus surveillance program [29].
Mosquitoes were trapped from July to September 2009 and from April to September 2010 at 15 sites in southern Germany and one in eastern Germany (see Table 1 and Figure 1), with $\mathrm{CO}_{2}$-baited EVS (encephalitis vector survey) traps (BioQuip, Compton, CA, USA) and with gravid traps (GT) designed according to the CDC gravid trap model 1712 (John W. Hock Company, Gainesville, FL, USA). GT's were used in urban and peridomestic areas, whereas EVS trapping was performed in natural habitats, e.g. wetlands, flood plains, wet woodlands. Mosquitoes collected were frozen at $-70^{\circ} \mathrm{C}$, transported to the laboratory, and identified on chill tables to species, species complex (An. maculipennis s.l.) or genus (Culex spp., which stands for $C x$. pipiens and $C x$. torrentium), and sex using morphological characteristics [32]. The processing over chill tables, however, could not always be conducted in 2010 .

As a large number of caught mosquitoes needed to be examined, they were merged into pools. For the further investigation it was not necessary to know exactly which mosquito was infected but which species at which trapping site was positive for filariae. Hence each pool normally consisted of up to 25 individuals from the same species collected at the same trapping site, placed in sterile $2-\mathrm{ml}$ cryovials, and then maintained at $-70^{\circ} \mathrm{C}$ until assayed. As shown in the results, knowing the species is important for the interpretation of the collected data. In the next step, each $5 \mu \mathrm{l}$ of extracted DNA of five pools and $65 \mu \mathrm{l}$ of water were merged to superpools, which were used for the first screen with the filarial-specific real-time PCR (dilution 1:10). The positive super-pools were further examined, by screening each single pool of the super-pool again with the filarial-specific real-time PCR.

Each mosquito pool was triturated in $500 \mu \mathrm{l}$ of cell culture medium (high-glucose Dulbecco's modified Eagle's medium [DMEM; Sigma-Aldrich, St. Louis, MO, USA] with $10 \%$ heat-inactivated foetal bovine serum, $100 \mathrm{U} / \mathrm{ml}$ penicillin, $100 \mu \mathrm{g} / \mathrm{ml}$ streptomycin, and 2.5 $\mu \mathrm{g} / \mathrm{ml}$ amphotericin B) with two stainless steel beads (5 $\mathrm{mm}$ ) in a TissueLyser (Qiagen, Hilden, Germany) for 2 $\mathrm{min}$ at 50 oscillation/s. The suspensions were clarified by centrifugation $(5000 \times g$ for $1 \mathrm{~min})$, and the supernatant was used for nucleic acid extraction with a QIAamp viral RNA mini kit according to the manufacturer's protocol (Qiagen, Hilden, Germany).

The filaria-specific real-time PCR, targeting a $94 \mathrm{bp}$ long fragment of the $12 \mathrm{~S}$ rRNA gene from the mitochondrial genome, was performed using the primers FILA-F (5' TGG ATT AGT ACC CAG GTA ATC 3') and FILA-R (5' CCA AAG AAA AAT CTA AAG TCA GTC $3^{\prime}$ ) and LNA probe FILA-P (5' FAM AAC+AAA $+\mathrm{ACT}+\mathrm{TTA}+\mathrm{CTCCCGA-BHQ1}$ 3' [FAM = 6-carboxyfluorescein; BHQ1 = black hole quencher 1]). Real-time 
Table 1 Collection and infection details of mosquitoes.

\begin{tabular}{|c|c|c|c|c|c|c|c|c|c|}
\hline $\begin{array}{l}\text { Site } \\
\text { No. }\end{array}$ & Federal State & Location & $\begin{array}{l}\text { Coordinates } \\
\text { N/E }\end{array}$ & $\begin{array}{l}\text { Trap } \\
\text { type }\end{array}$ & $\begin{array}{l}\text { No. of } \\
\text { mosquitoes }\end{array}$ & $\begin{array}{l}\text { No. of } \\
\text { pools }\end{array}$ & $\begin{array}{l}\text { Pool } \\
\text { sizes }\end{array}$ & $\begin{array}{l}\text { No. of pos. } \\
\text { pools }\end{array}$ & $M I R^{*}$ \\
\hline & 2009 & & & & & & & & \\
\hline 1 & B-W & Weinheim & $49^{\circ} 33^{\prime} / 8^{\circ} 40^{\prime}$ & GT & 3699 & 165 & $1-25$ & 34 & 9.2 \\
\hline \multirow[t]{2}{*}{2} & B-W & $\begin{array}{l}\text { Wagbachniederung } \\
\text { (Wäghäusel) }\end{array}$ & $\begin{array}{l}49^{\circ} 15^{\prime} 25^{\prime \prime} / 8^{\circ} \\
31^{\prime} 08^{\prime \prime}\end{array}$ & GT & 888 & 45 & $1-26$ & 11 & 12.4 \\
\hline & & & & EVS & 7237 & 336 & $2-28$ & 18 & 2.5 \\
\hline 3 & R-P & $\begin{array}{l}\text { Kühkopf Knoblochsaue/ } \\
\text { Flotzengrün }\end{array}$ & $49^{\circ} 49^{\prime} / 8^{\circ} 24^{\prime}$ & EVS & 2532 & 134 & $2-25$ & 0 & 0 \\
\hline \multirow[t]{3}{*}{4} & & & $49^{\circ} 17^{\prime} / 8^{\circ} 25^{\prime}$ & EVS & 166 & 9 & $1-25$ & 4 & 24.1 \\
\hline & Total 2009 & & & & 14522 & 666 & $1-28$ & 67 & 4.6 \\
\hline & 2010 & & & & & & & & \\
\hline 5 & Bav & Chiemsee & $\begin{array}{l}47^{\circ} 51^{\prime} 28^{\prime \prime} / 12^{\circ} \\
31^{\prime} 08^{\prime \prime}\end{array}$ & EVS & 16583 & 680 & $1-27$ & 1 & 0.06 \\
\hline 6 & Bav & Isar & $\begin{array}{l}48^{\circ} 47^{\prime} 14^{\prime \prime} / 12^{\circ} \\
55^{\prime} 07^{\prime \prime}\end{array}$ & EVS & 3314 & 137 & $5-25$ & 0 & 0 \\
\hline 7 & Bav & Osterseen & $\begin{array}{l}47^{\circ} 46^{\prime} 23^{\prime \prime} / 11^{\circ} \\
18^{\prime} 25^{\prime \prime}\end{array}$ & EVS & 8030 & 331 & $1-25$ & 0 & 0 \\
\hline \multirow[t]{3}{*}{8} & B-W & Lake Konstanz & $\begin{array}{l}47^{\circ} 44^{\prime} 34^{\prime \prime} / 8^{\circ} \\
58^{\prime} 59^{\prime \prime}\end{array}$ & EVS & 10092 & 442 & $1-25$ & 1 & 0.09 \\
\hline & & & $\begin{array}{l}47^{\circ} 44^{\prime} 17^{\prime \prime} / 8^{\circ} \\
58^{\prime} 52^{\prime \prime}\end{array}$ & & & & & & \\
\hline & & & $\begin{array}{l}47^{\circ} 41^{\prime} 40^{\prime \prime} / 9^{\circ} \\
06^{\prime} 53^{\prime \prime}\end{array}$ & & & & & & \\
\hline 9 & B-W & Großsachsen & $49^{\circ} 31^{\prime} / 8^{\circ} 40^{\prime}$ & GT & 3327 & 175 & $1-25$ & 99 & 29.75 \\
\hline 10 & B-W & Karlsruhe-Rott Island & $\begin{array}{l}49^{\circ} 09^{\prime} 02^{\prime \prime} / 8^{\circ} \\
23^{\prime} 10^{\prime \prime}\end{array}$ & EVS & 11960 & 506 & $1-50$ & 3 & 0.25 \\
\hline 11 & B-W & Karlsruhe-Knielinger Lake & $\begin{array}{l}49^{\circ} 02^{\prime} 04^{\prime \prime} / 8^{\circ} \\
18^{\prime} 50^{\prime \prime}\end{array}$ & EVS & 13 & 4 & $1-8$ & 0 & 0 \\
\hline 12 & B-W & Karlsruhe-Russheim & $\begin{array}{l}49^{\circ} 11^{\prime} 26^{\prime \prime} / 8^{\circ} \\
25^{\prime} 01^{\prime \prime}\end{array}$ & EVS & 84 & 7 & $2-25$ & 0 & 0 \\
\hline 13 & B-W & Karlsruhe-Stutensee & $49^{\circ} 04^{\prime} / 8^{\circ} 30^{\prime}$ & EVS & 3 & 2 & $1-2$ & 0 & 0 \\
\hline 1 & B-W & Weinheim & $49^{\circ} 33^{\prime} / 8^{\circ} 40^{\prime}$ & GT & 1607 & 103 & $1-25$ & 40 & 24.89 \\
\hline 2 & B-W & $\begin{array}{l}\text { Wagbachniederung } \\
\text { (Wäghäusel) }\end{array}$ & $\begin{array}{l}49^{\circ} 15^{\prime} 25^{\prime \prime} / 8^{\circ} \\
31^{\prime} 08^{\prime \prime}\end{array}$ & EVS & 678 & 41 & $1-30$ & 4 & 5.89 \\
\hline 14 & $\mathrm{R}-\mathrm{P}$ & Haßloch & $49^{\circ} 18^{\prime} / 8^{\circ} 17^{\prime}$ & EVS & 888 & 48 & $1-25$ & 0 & 0 \\
\hline 15 & R-P & Mainz & $49^{\circ} 45^{\prime} / 8^{\circ} 18^{\prime}$ & EVS & 356 & 21 & $1-25$ & 0 & 0 \\
\hline \multirow[t]{3}{*}{16} & S-A & Coswig/Elbe & $51^{\circ} 51^{\prime} / 12^{\circ} 26^{\prime}$ & EVS & 11698 & 484 & $1-25$ & 1 & 0.08 \\
\hline & Total 2010 & & & & 68633 & 2981 & $1-50$ & 149 & 2.17 \\
\hline & $\begin{array}{l}\text { Total } 2009 \text { and } \\
2010\end{array}$ & & & & 83155 & 3647 & $1-50$ & 216 & 2.6 \\
\hline
\end{tabular}

For general information on species compositions see [31].

Abbreviations: B-W: Baden-Württemberg; Bav: Bavaria; EVS: Encephalitis vector survey trap; GT: Gravid trap; MIR: minimum infection rate; R-P: RhinelandPalatinate; S-A: Saxonia-Anhalt. *These Minimum Infection Rates apply to the locality and year only, and include all local mosquito species and both parasite species, respectively. For mosquito species-wise MIR's please refer to the Results section.

PCR was performed with QuantiFast Probe PCR kit according to the manufacturer's protocol (Qiagen).

Real-time PCR-positive pools were subsequently examined by a conventional PCR (with subsequent gel electrophoresis) targeting an approx. 500 bp long fragment of $12 \mathrm{~S}$ rRNA (ribosomal RNA), $16 \mathrm{~S}$ rRNA and COI (cytochrome oxidase I gene) [33,34]. The resulting PCR products were purified with the NucleoSpin Extract
II kit (Macherey-Nagel, Düren, Germany) and commercially sequenced in both directions using the PCR primers (Seqlab GmbH, Göttingen, Germany) by direct sequencing of PCR products.

The respective sequences of six specimens are deposited in [GenBank: JN228376-JN228381]. Sequences were aligned with ClustalW2 [35], after adding several reference sequences from GenBank. The alignment file was 


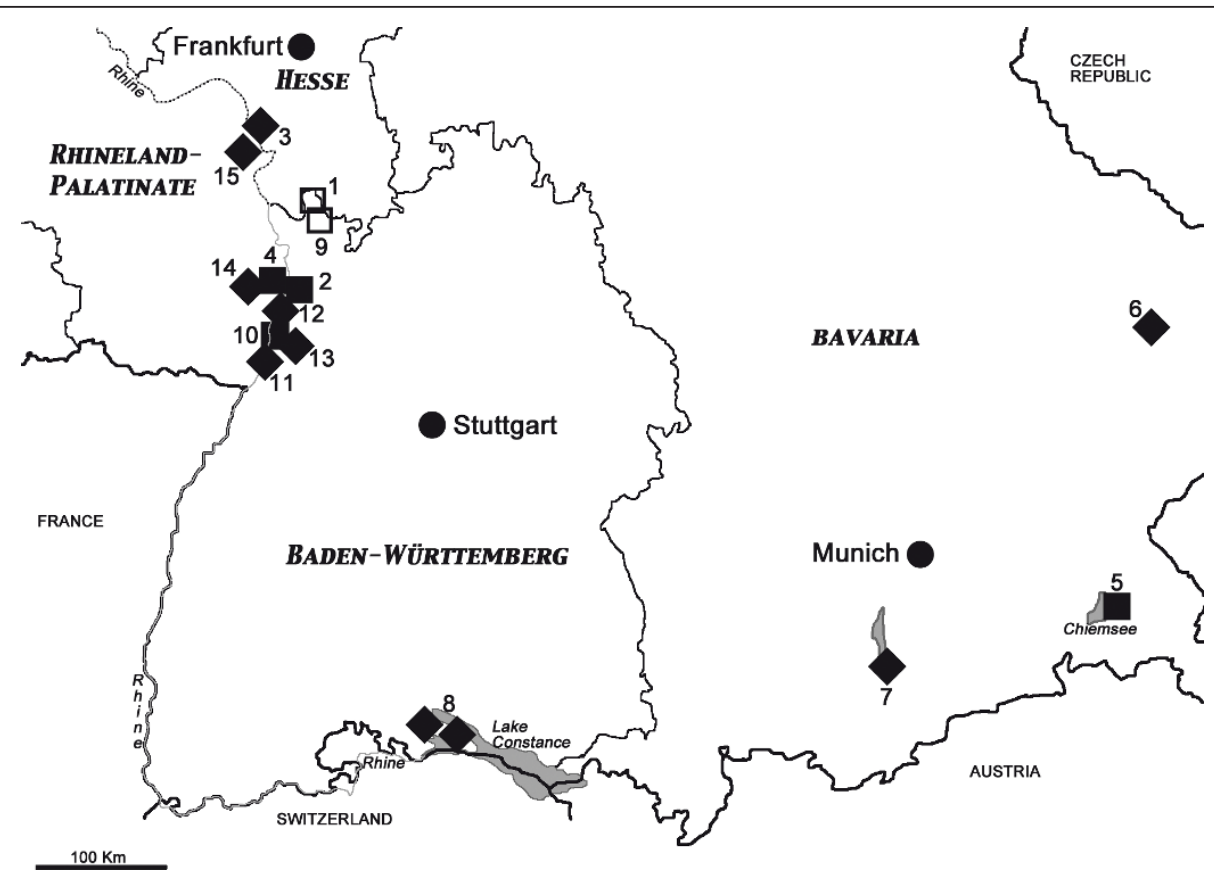

Figure 1 Locations of the study sites in south-western Germany. Numbers refer to Table 1 (site 16 not shown on this map). Symbols: diamonds, mosquito collection sites; open squares, positive mosquitoes for unidentified filariae; solid squares, positive mosquitoes for Setaria tundra.

uploaded in MEGA 5.05 [36], which was used to calculate the taxon ID tree (Neighbour-Joining algorithm) with consensus sequences in comparison with previously published species sequences (see Figure 2).

\section{Results and discussion}

A total of 14,522 female mosquitoes were collected in 2009 (Table 1). The collections consisted of Culex spp. (confirmed: $C x$. pipiens and Cx. torrentium; not confirmed: Cx. modestus, Cx. territans), Aedes vexans, Ae. cinereus, Ochlerotatus cantans, Oc. sticticus, Culiseta annulata, Anopheles maculipennis s.l., and An. claviger. The most abundant species were Culex spp. (35\%), An. claviger (24\%) and the floodwater mosquito Ae. vexans (20\%). The mosquitoes most frequently trapped with the gravid traps (GT) were Culex spp. (99\%), while the total catches in GTs were 4,587, compared with 9,935 specimens trapped with the EVS traps (proportion 1:2.2).

Overall, in the first-round real-time PCRs, 218 superpools, which had been derived from 666 original pools, were assayed for the presence of filariae. Of the 218 super-pools, $63(29 \%)$ gave filaria-positive results.

Of the 63 positive super-pools, all respective original pools (189) were screened by real-time PCR, and 67 (35.4\%) were shown to be positive, of which 24 were confirmed by $12 \mathrm{~S}$ PCR (23 were sequenced). In 17 cases (27\%), the second round-PCR did not confirm the positive first-round result.

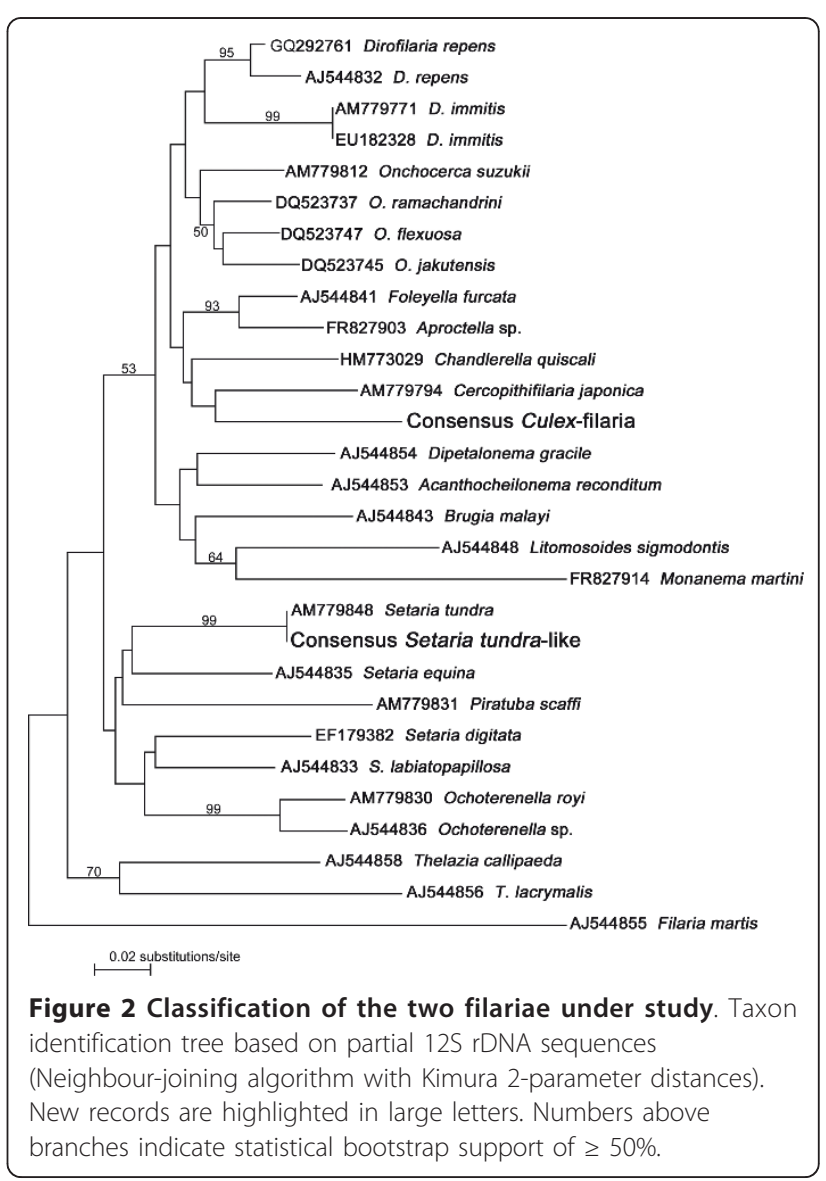


Of 226 Culex spp. pools consisting of 5106 individuals, 44 pools were filaria-positive by real-time PCR, which corresponds to $19.5 \%$ positive Culex spp. pools and a minimum infection rate (MIR: [number of positive pools/total specimens tested] $\times 1000)$ of 8.6 per 1000 mosquitoes.

Of 369 non-Culex pools (excluding Culiseta and $A n$. maculipennis s.l.) consisting of 8538 individuals of $A e$. vexans, Oc. cantans, Oc. sticticus and An. claviger, 23 were filaria-positive, which corresponds to $6 \%$ positive pools and a MIR of 2.7. In terms of species, the MIRs were as follows: Oc. sticticus 6.2, An. claviger 2.3, Ae. vexans 1,7. The highest MIR at a single locality was 24.1 at Flotzengrün (Table 1), which was entirely due to positive Ae. vexans pools.

In 2010, a total of 68,633 female mosquitoes were collected and processed into 2981 pools. In addition to the species caught in 2009, Oc. annulipes, Oc. communis, Oc. punctor, Oc. rusticus and An. plumbeus were caught. Aedes vexans was the dominating species (50\%), followed by Oc. sticticus (35\%) and Culex spp. (8\%). The mosquitoes most frequently trapped with the GT were again Culex spp. (>99\%), with a total proportion of GT versus EVS of 1:13.

Of the 2981 pools, 149 were tested filaria-positive by real-time PCR $(5 \%)$, of which 54 were confirmed by either $12 \mathrm{~S}$, or $16 \mathrm{~S}$ or $\mathrm{COI} \mathrm{PCR}$, and $2712 \mathrm{~S}$ products were sequenced. In 78 cases (52\%), the second-round PCR did not confirm the positive first-round result.

Of 307 Culex spp. pools consisting of 5417 individuals, 140 pools were filaria-positive by real-time PCR, which corresponds to $45 \%$ positive Culex spp. pools and a MIR of 25.8 .

Of 2674 non-Culex pools consisting of 63,216 individuals of 12 different species, only nine were filaria-positive (four Ae. vexans, two An. claviger, two Cs. annulata, one Oc. sticticus), which corresponds to $0.3 \%$ positive pools and a MIR of 0.1. The highest MIR at a single locality was 29.75 at Großsachsen (Table 1), which was entirely due to positive Culex spp. pools.

In 2009 , fourteen closely related filarial sequences resembling that of Setaria tundra (identity of consensus with $S$. tundra is $97-99 \%$ ) were derived from five pools of Oc. sticticus, four pools each of Ae. vexans and An. claviger, and one pool of Oc. cantans. In 2010, only two additional $S$. tundra-like sequences were revealed from one Oc. sticticus pool and one Ae. vexans pool. The $S$. tundra sequences (as consensus in Figure 2) unequivocally cluster with other S. tundra (99\% bootstrap support).

Additionally, in 9 and 25 pools of Culex sp. (2009 and 2010, respectively) sequences of unspecified filarial origin were derived, but presumably all of the same species. In the $12 \mathrm{~S}$ taxon identification tree (Figure 2) these
Culex filariae (as consensus) do not cluster with any of those included in the tree analysis and cannot even be assigned unequivocally to any of the genera sequenced so far (see also below). An additional analysis with a reduced number of taxa (all those in the branch above Dipetalonema in Figure 2) revealed an identical topology, but with higher statistical bootstrap support (data not shown). A BLAST search of GenBank retrieves the highest sequence identity (86\%) with Onchocerca suzu$k i$, a parasite of Japanese bovids. However, the tree (in Figure 2) shows that this does not correspond to a close relationship, as O. suzukii clusters with other Onchocerca species.

\section{Geographic pattern}

As the yet unidentified filarial species was exclusively found in Culex mosquitoes, it is not surprising that it was most abundant in those places where mainly Culex spp. were caught using gravid traps, which were Weinheim and Großsachsen (Figure 1). Only three positive pools originated from the site at Wagbachniederung in 2009. All three sites are located in the north of the state of Baden-Württemberg (see also below).

Setaria tundra appears to be more widespread: it was found in various mosquito species in the states of Bavaria, Rhineland-Palatinate and Baden-Württemberg.

\section{Potential vertebrate hosts and vectors}

At this stage, we can only speculate about the potential vertebrate hosts of the two different filariae. In the case of Setaria tundra it seems prudent to assume roe-deer as the vertebrate host, as in the past this has been reported from Germany [21,37] and neighbouring countries [38-40]. In southern Germany the prevalence of $S$. tundra in roe-deers ranges between $1.6 \%$ in North Rhine-Westphalia [37] and 12.3\% in northern Bavaria [21]. In Finland, roe-deer seem to be the main reservoir, but reindeer and moose can also be infected [41]. The transmission of $S$. tundra by various German mosquito species such as Oc. sticticus, Ae. vexans and An. claviger is similar to findings from Finland, where Ae. communis, Ae. punctor, Ae. hexodontus and Ae. excrucians were incriminated as natural vectors [28]. The veterinary importance of $S$. tundra is due to a reported outbreak of peritonitis with significant economic losses in Finnish semi-domesticated reindeer in 2003-5 [42]. Similar outbreaks may occur in any other wild or semi-domesticated cervid population outside Finland, e.g. in zoos.

Regarding the filarial species derived from Culex mosquitoes, birds might serve as vertebrate hosts, because of the ornithophilic behavior of most Culex species in Europe [38]. Potential bird parasite genera known from Europe are Cardiofilaria, Chandlerella, Eufilaria, Eulimdana, Pelecitus, Pseudlemdana, Sarconema and 
Splendidofilaria [12,43-49], some of which are found in common birds such as Blackbirds (Turdus merula), Magpies (Pica pica) or Great Tits (Parus major) $([12,50])$, others in domesticated exotic birds [51]. However, only certain Cardiofilaria and Pelecitus species are known to be vectored by culicines from Asia and North America [12,52]. A single record from German birds of prey [47] makes Cardiofilaria pavlovskyi the favourite candidate for our unidentified specimens. It is also known from various birds in Spain, France, Poland and Latvia $[12,45,49,50]$. Final conclusions are prevented by the paradox that on one hand, sequences are not available for Cardiofilaria and for the majority of the about 90 known genera of onchocercid filariae [17], of which only 20 genera are currently represented in GenBank. On the other hand our study protocol did not allow morphological examination prior to homogenization for DNA extraction, and the same applies to most if not all vector-borne specimens listed in GenBank. The only bird parasite that was confirmed by morphology and DNA sequencing during a bird die-off in late 2011 was Diplotriaena sp. (Nematoda: Diplotriaenidae) in two dead blackcaps (Sylvia atricapilla), but the 12S DNA sequence turned out to be very different from the Culex filariae (unpublished observations by the authors).

It is generally assumed that avian filarioid parasites are rarely pathogenic, and clinical signs may occur only in some bird species or in some individuals within one species [53].

\section{Conclusions}

This study searched for filarial human pathogens in German mosquitoes, for instance Dirofilaria species. In about 83,000 mosquitoes tested, no filarial DNA sequences were found that matched those known for the two potential targets, i.e. D. immitis or D. repens. Hence it remains open whether one or both parasites could be transmitted autochthonously by indigenous mosquitoes. The absence of Dirofilaria spp. or other zoonotic filariae in our sample allows the conclusion that the risk of autochthonous infection in Germany is still very low, although dirofilariasis is emerging and spreading in Europe [10].

The generalized filarial PCR primers used in our study allowed the detection of two other species one of which could be unambiguously identified as Setaria tundra. The other remains unidentified, but is likely a bird parasite.

We do not have any published information regarding human infection with Setaria tundra or one or the other bird filariae, but it could be possible occasionally since some of the mosquito species found to be infected are known to feed on humans. In this case, infections are likely to be symptomless, given the lack of any case report. In summary, the synergism between entomologists, virologists and parasitologists, combined with state-of-the-art methods allows a very efficient nearreal-time monitoring of a wide spectrum of both human and veterinary pathogens, including the discovery of yet unknown or neglected species.

\section{List of abbreviations used}

Bp: Base pair; COI: Cytochrome oxidase I gene; EVS: Encephalitis vector survey trap; GT: Gravid trap; MIR: Minimum infection rate; mtDNA: Mitochondrial DNA; rRNA: Ribosomal DNA.

\section{Acknowledgements}

We thank Ms. Deborah Maus and Mrs. Alexandra Bialonski for laboratory assistance during the PCR pool screening. The authors would like to thank the anonymous reviewers for their valuable comments and suggestions to improve the earlier draft of this manuscript.

\section{Author details}

${ }^{1}$ German Mosquito Control Association (KABS), Waldsee, Germany. 2University of Heidelberg, Heidelberg, Germany. ${ }^{3}$ Department of Parasitology, Bernhard Nocht Institute for Tropical Medicine, Hamburg, Germany. ${ }^{4}$ Department of Virology, Bernhard Nocht Institute for Tropical Medicine, Hamburg, Germany. ${ }^{5}$ Department of Tropical Medicine, Bundeswehr Hospital Hamburg, Hamburg, Germany.

\section{Authors' contributions}

CC: As part of her doctoral thesis she conducted a significant part of the 2010 mosquito collection field-work, executed all PCRs, analysed the data and contributed to the manuscript drafting. NB coordinated most of the field-work and gave significant input to the study design and execution. SP established the conventional filaria PCR diagnostics and contributed substantially to the manuscript drafting. HJ: As part of her doctoral thesis she conducted all 2009 and a big part of the 2010 field-work, did most DNA extractions in conjunction with the arbovirus project and was involved in the data analysis and manuscript drafting. JS-C supervised the lab work, designed the filarial real-time PCR and contributed to the manuscript drafting. AK contributed to the study design and wrote the manuscript. All authors read and approved the final version of the manuscript

\section{Authors' information}

CC is a doctoral student of Biology at the University of Heidelberg. NB is assistant professor at the University of Heidelberg, the coordinator of the German arbovirus surveillance and mosquito monitoring program and managing director of the KABS. SP is clinical microbiologist and parasitologist at the Bernhard-Nocht-Institute for Tropical Medicine. $\mathrm{HJ}$ is a doctoral student of Biology at the University of Heidelberg. JS-C is assistant professor of virology at the University of Hamburg, and head of the arbovirus lab group at the Bernhard-Nocht-Institute for Tropical Medicine. AK is assistant professor of entomology at the University of Hamburg, and head of the Bundeswehr lab group for medical entomology at the BernhardNocht-Institute for Tropical Medicine.

\section{Competing interests}

The authors declare that they have no competing interests.

Received: 26 October 2011 Accepted: 11 January 2012 Published: 11 January 2012

\section{References}

1. Morales-Hojas R: Molecular systematics of filarial parasites, with an emphasis on groups of medical and veterinary importance, and its relevance for epidemiology. Infect Genet Evol 2009, 9:748-759.

2. Krauss $H$, Weber A, Appel M, Enders B, Isenberg HD, Schiefer HG, Slenczka W, Graevenitz von A, Zahner H: Zoonoses: infectious diseases transmissible from animals to humans Washington: ASM Press; 2003.

3. Muller R: Worms and human disease Wallingford: CABI Publishing; 2002. 
4. Otranto D, Diniz DG, Dantas-Torres F, Casiraghi M, de Almeida IN, de Almeida LN, dos Santos JN, Furtado AP, de Almeida Sobrinho EF, Bain O: Human intraocular filariasis caused by Dirofilaria sp. Nematode, Brazil. Emerg Infect Dis 2011, 17:863-866.

5. Otranto D, Sakru N, Testini G, Gürlü VP, Yakar K, Lia RP, Dantas-Torres F, Bain O: Case report: First evidence of human zoonotic infection by Onchocerca lupi (Spirurida, Onchocercidae). Am J Trop Med Hyg 2011, 84:55-58.

6. Otranto D, Eberhard ML: Zoonotic helminths affecting the human eye. Parasit Vectors 2011, 4:41.

7. Pampiglione S, Rivasi F: Human dirofilariasis due to Dirofilaria (Nochtiella) repens: an update of world literature from 1995 to 2000. In Dirofilaria immitis and D. repens in dog and cat and human infections. Edited by: Genchi C, Rinaldi L, Cringoli G. Naples: Rolando Editore; 2007:81-116, [Cringoli G (Series Editor) Mappe Parassitologiche, vol 8.].

8. Pantchev N, Norden N, Lorentzen L, Rossi M, Rossi U, Brand B, Dyachenko V: Current surveys on the prevalence and distribution of Dirofilaria spp. in dogs in Germany. Parasitol Res 2009, 105:S63-S74.

9. Sassnau R, Dyachenko V, Pantchev N, Stöckel F, Dittmar K, Daugschies A: Dirofilaria-repens-Befall in einem Schlittenhunde-Rudel im Land Brandenburg. Tierärztl Prax 2009, 37(K):95-101.

10. Genchi C, Kramer LH, Rivasi F: Dirofilarial infections in Europe. Vector Borne Zoonotic Dis 2011, 11:1307-1317.

11. Bain O, Chabaud AG: Atlas des larves infestantes de Filaires. Trop Med Parasitol 1986, 37:301-40

12. Anderson RC: Nematode parasites of vertebrates: their development and transmission Wallingford: CABI Publishing; 2000.

13. Severson DW: Applications of molecular marker analysis to mosquito vector competence. Parasitol Today 1994, 10:336-340.

14. McManus DP, Bowles J: Molecular genetic approaches to parasite identification: their value in diagnostic parasitology and systematics. Int J Parasitol 1996, 26:687-704.

15. Chambers EW, McClintock SK, Avery MF, King JD, Bradley MH, Schmaedick MA, Lammie PJ, Burkot TR: Xenomonitoring of Wuchereria bancrofti and Dirofilaria immitis infections in mosquitoes from American Samoa: trapping considerations and a comparison of polymerase chain reaction assays with dissection. Am J Trop Med Hyg 2009, 80:774-781.

16. Manrique-Saide P, Escobedo-Ortegón J, Bolio-González M, Sauri-Arceo C, Dzib-Florez S, Guillermo-May G, Ceh-Pavía E, Lenhart A: Incrimination of the mosquito, Aedes taeniorhynchus, as the primary vector of heartworm, Dirofilaria immitis, in coastal Yucatan, Mexico. Med Vet Entomol 2010, 24:456-460.

17. Ferri E, Bain O, Barbuto M, Martin C, Lo N, Uni S, Landmann F, Baccei SG, Guerrero R, de Souza Lima S, Bandi C, Wanji S, Diagne M, Casiraghi M: New insights into the evolution of Wolbachia infections in filarial nematodes inferred from a large range of screened species. PLOS ONE 2011, 6 : e20843.

18. Schulz-Key H: Untersuchungen über die Filarien der Cerviden in Süddeutschland. 2. Die Filarien des Rothirsches. Tropenmed Parasit 1975 26:348-358.

19. Zahner S, Schulz-Key H: Rinderonchozerkose in Süddeutschland: Verteilung der Mikrofilarien in ihrem Wirtshabitat. Mitt Österr Ges Trop Med Parasit 1990, 12:87-94.

20. Jelinek T, Schulte-Hillen J, Löscher T: Human dirofilariasis. Int J Dermatol 1996, 35:872-875.

21. Büttner K: Untersuchungen zur Parasitierung des Rehwildes bei steigendem Jagddruck. Z Jagdwiss 1978, 24:139-155.

22. Hamel D, Axt H, Pfister K: First report on Parafilaria bovicola (Nematoda: Filaroidea) in Germany. Res Vet Sci 2010, 89:209-211.

23. Schulz-Key H: Untersuchungen über die Filarien der Cerviden in Süddeutschland. 3. Die Filarien des Rehes (Capreolus capreolus) und des Damhirsches (Dama dama). Tropenmed Parasit 1975, 26:494-498.

24. Schulz-Key H, Wenk P: The transmission of Onchocerca tarsicola (Filarioidea: Onchocercidae) by Odagmia ornata and Prosimulium nigripes (Diptera: Simuliidae). J Helminthol 1981, 55:161-166.

25. Fukuda M, Takaoka H, Uni S, Bain O: Infective larvae of five Onchocerca species from experimentally infected Simulium species in an area of zoonotic onchocerciasis in Japan. Parasite 2008, 15:111-119.

26. Fukuda M, Otsuka Y, Uni S, Bain O, Takaoka H: Molecular identification of infective larvae of three species of Onchocerca found in wild-caught females of Simulium bidentatum in Japan. Parasite 2010, 17:39-45.
27. Cancrini G, Gabrielli S: Vectors of Dirofilaria nematodes: biology, behaviour and host/parasite relationships. In Dirofilaria immitis and D. repens in dog and cat and human infections. Edited by: Genchi C, Rinaldi L, Cringoli G. Naples: Rolando Editore; 2007:47-59, [Cringoli G (Series Editor) Mappe Parassitologiche, vol 8.]

28. Laaksonen S, Solismaa M, Kortet R, Kuusela J, Oksanen A: Vectors and transmission dynamics for Setaria tundra (Filarioidea; Onchocercidae), a parasite of reindeer in Finland. Parasit Vectors 2009, 2:3.

29. Jöst H, Bialonski A, Storch V, Günther S, Becker N, Schmidt-Chanasit J: Isolation and phylogenetic analysis of Sindbis viruses from mosquitoes in Germany. J Clin Microbiol 2010, 48:1900-1903.

30. Jöst H, Bialonski A, Schmetz C, Günther S, Becker N, Schmidt-Chanasit J: Isolation and phylogenetic analysis of Batai virus, Germany. Am J Trop Med Hyg 2011, 84:241-243.

31. Jöst H, Bialonski A, Maus D, Sambri V, Eiden M, Groschup MH, Günther S, Becker N, Schmidt-Chanasit J: Isolation of Usutu virus in Germany. Am J Trop Med Hyg 2011, 85:551-553.

32. Becker N, Petrić D, Zgomba M, Boase C, Madon M, Dahl C, Kaiser A: Mosquitoes and their control Berlin: Springer-Verlag; 2010.

33. Krueger A, Fischer P, Morales-Hojas R: Molecular phylogeny of the filaria genus Onchocerca with special emphasis on Afrotropical human and bovine parasites. Acta Trop 2007, 101:1-14.

34. Casiraghi M, Anderson TJC, Bandi C, Bazzocchi C, Genchi C: A phylogenetic analysis of filarial nematodes: comparison with the phylogeny of Wolbachia endosymbionts. Parasitology 2001, 122:93-103.

35. Larkin MA, Blackshields G, Brown NP, Chenna R, McGettigan PA, McWilliam H, Valentin F, Wallace IM, Wilm A, Lopez R, Thompson JD, Gibson TJ, Higgins DG: ClustalW and ClustalX version 2.0. Bioinformatics 2007, 23:2947-2948.

36. Tamura K, Peterson D, Peterson N, Stecher G, Nei M, Kumar S: MEGA5: Molecular Evolutionary Genetics Analysis using Maximum Likelihood, Evolutionary Distance, and Maximum Parsimony Methods. Mol Biol Evol 2011, 28:2731-2739.

37. Rehbein S, Lutz W, Visser M, Winter R: Beiträge zur Kenntnis der Parasitenfauna des Wildes in Nordrhein-Westfalen. 1. Der Endoparasitenbefall des Rehwildes. Z Jagdwiss 2000, 46:248-269.

38. Böhm LK, Supperer R: Untersuchungen über Setarien (Nematoda) bei heimischen Wiederkäuern und deren Beziehung zur "Epizootischen Cerebrospinalen Nematodiasis" (Setariosis). Z Parasitenk 1955, 17:165-174.

39. Kutzer E, Hinaidy HK: Die Parasiten der wildlebenden Wiederkäuer Österreichs. Z Parasitenk 1969, 32:354-368.

40. Favia G, Cancrini G, Ferroglio E, Casiraghi M, Ricci I, Rossi L: Molecular assay for the identification of Setaria tundra. Vet Parasitol 2003, 117:139-145.

41. Laaksonen S, Solismaa M, Orro T, Kuusela J, Saari S, Kortet R, Nikander S, Oksanen A, Sukura A: Setaria tundra microfilariae in reindeer and other cervids in Finland. Parasitol Res 2009, 104:257-265.

42. Laaksonen S, Kuusela J, Nikander S, Nylund M, Oksanen A: Outbreak of parasitic peritonitis in reindeer in Finland. Vet Rec 2007, 160:835-841.

43. Guildal JA, Settnes OP: Peritracheal filariosis in a pigeon caused by Pelecitus clava (Wedl, 1856). Nord Vet Med 1968, 20:68-70.

44. López-Caballero EJ: Chandlerella hispanica n. sp., filarial parasita de los zoozales. Bol R Soc Esp Hist Nat 1974, 72:145-151.

45. López-Caballero EJ: Study on microfilariae, 1: The microfilaria of Cardofilaria pavlovskyi Strom, 1937. (Nematoda: Filarioidea). Rev Iber Parasitol 1982, 42:57-69.

46. Bartlett CM, Greiner EC: A revision of Pelecitus Railliet \& Henry, 1910 (Filarioidea, Dirofilariinae) and evidence for the capture by mammals of filarioids from birds. Bull Mus natn Hist nat Paris 4th ser 1986, 8:47-99.

47. Krone O: Endoparasiten (Faunistik, Epizootiologie, Pathogenität) be wildlebenden Greifvögeln aus drei verschiedenen Gebieten Deutschlands. J Ornithol 1999, 140:213-214.

48. Haas M, Baruš V, Benedikt V, Literák I: Microfilariae in birds in the Czech Republic, including a note on adult nematodes Eufilaria delicata in a song thrush Turdus philomelos. Parasitol Res 2011, 109:645-55.

49. Fauna Europaea. [http://www.faunaeur.org].

50. Okulewicz A: Pasożytnicze nicienie Sikor (Paridae) w Polsce. Wiad Parazytol 1991, 37:491-498.

51. Kummerfeld N, Daugschies A: Filarien (Pelecitus sp., Chandlerella sp.) bei Blaustirnamazonen (Amazona aestiva) und Alexandersittich (Psittacula eupatria). Kleintierpraxis 1989, 34:521-524. 
52. Dissanaike AS, Fernando MA: Cardiofilaria nilesi n.sp., recovered from a chicken experimentally infected with infective larvae from Mansonia crassipes. J Helminthol 1965, 39:151-158.

53. Bartlett CM: Filarioid nematodes. In Parasitic diseases of wild birds. Edited by: Atkinson CT, Thomas NJ, Hunter DB. Ames: Wiley-Blackwell; 2008:439-462.

doi:10.1186/1756-3305-5-14

Cite this article as: Czajka et al: Molecular detection of Setaria tundra (Nematoda: Filarioidea) and an unidentified filarial species in mosquitoes in Germany. Parasites \& Vectors 2012 5:14.

Submit your next manuscript to BioMed Central and take full advantage of:

- Convenient online submission

- Thorough peer review

- No space constraints or color figure charges

- Immediate publication on acceptance

- Inclusion in PubMed, CAS, Scopus and Google Scholar

- Research which is freely available for redistribution

Submit your manuscript at www.biomedcentral.com/submit
() Biomed Central 